\title{
Insulin Resistance, Obesity and Polycystic Ovarian Syndrome in Diabetic Patients
}

\begin{abstract}
Aziz KMA*
Professor of Diabetes and Metabolism; Research Scientist and Clinical Investigator, Aseer Diabetes Center of Aseer Central Hospital, Saudi Arabia
\end{abstract}

*Corresponding author: Aziz KMA, Diabetology Clinic, Aseer Diabetes Center of Aseer Central Hospital, Ministry of Health, P.O.Box 34, Abha, Saudi Arabia, Tel: 00966-568361040; E-mail: drkamran9999@yahoo.com

\section{Metabolic Mechanisms of Insulin Resistance}

Ingestion of diets with high fats or lipids is associated with obesity and increased storage of triglycerides at sites other than adipose tissue, including skeletal muscle, liver, the heart, and kidney. These changes cause chronic elevations in circulating free fatty acids and triacylglycerols (TAG). Extensive research has shown that adipose tissue is an important endocrine organ. Adipose cells produce a variety of hormones and cytokines (referred to collectively as "adipokines") which regulate both lipid and glucose metabolism and play a direct role in development of insulin resistance and diabetes. Some of them are peptide hormones such as adiponectin (also Acrp30) and resistin, and proinflammatory cytokines such as interleukin-6 (IL-6) and tumor necrosis factor- $\alpha$ $(\mathrm{TN}-\alpha)[1-7]$.

Two best-characterized antidiabetic adipokines, leptin and adiponectin have been shown to decrease triglyceride synthesis, promote fatty acid catabolism, and enhance insulin action in both skeletal muscle and the liver. Furthermore, obesity leads to a state of leptin resistance, and one of adiponectin deficiency. Moreover, insulin resistance is associated with increased production of resistin, IL-6, TNF- $\alpha$, and retinol-binding protein-4 (RBP4) by adipose tissue, all of which have been shown to induce insulin resistance in muscle and the liver. Leptin infusion ameliorates insulin resistance in lipoatrophic mice, whereas transplantation of fat from leptin-deficient mice into such animals fails to improve insulin sensitivity.
Furthermore, leptin administration to humans with severe lipodystrophy partially reverses their severe insulin resistance and hyperlipidemia. Down regulation of GLUT4 and glucose transport selectively in adipose tissue has been shown to cause insulin resistance in muscle, perhaps by diverting FFAs and other fuels from adipose to non-adipose tissues [8-10].

\section{Markers of Insulin Resistance: Elevated Plasma FFA in Type-2 Diabetic State}

Postprandial FFA levels are usually higher in obese, insulin resistant individuals and in individuals with type2 diabetes; elevated plasma FFA levels are independent predictor of progression to type-2 diabetes in Caucasians and Pima Indians.FFA correlated with low insulinmediated glucose disposal in these individuals, and are associated with an increased risk of myocardial ischemia, and also correlated to carotid intima-media thickness and endothelial dysfunction. FFA enhances basal and insulinstimulated insulin secretion. However, chronic elevations of FFAs may contribute to peripheral and hepatic insulin resistance, and $\beta$-cell dysfunction in type- 2 diabetes, and exhibit reduced insulin-stimulated muscle glucose uptake. FFAs induce hepatic insulin resistance in the basal state, which is the cause of impaired insulin-mediated suppression of glycogenolysis. Hence, FFAs increase the de novo synthesis of glucose by the liver. Furthermore, FFA also increases the secretion of very low-density lipoprotein (VLDL). Increased levels of FFA reduce glucose-stimulated insulin secretion (GSIS) and decreases $\beta$-cell mass as well ( $\beta$-cell lipotoxicity) [11-18]. 


\section{Diabetes and Obesity International Journal}

\section{Obesity and Type-2 Diabetes}

Obesity can be defined as an excessive amount of body fat (body mass index, BMI $\geq 30 \mathrm{~kg} / \mathrm{m}^{2}$ ). Obesity has been suggested increasing an individual's risk for cancer, gastrointestinal diseases, arthritis, diabetes, and cardiovascular disease. Obesity and insulin resistance are integrally related. Type- 2 diabetes and obesity often coexist together; treatment of both should be initiated together, with lifestyle modifications and pharmacologic therapy. Surgical options, including gastric bypass, are now considered best options which ameliorates both diabetes and obesity [19-21].

\section{Polycystic Ovary Syndrome (PCO) and Metabolic Complications}

Recent research trials suggests that PCOS is associated with metabolic complications including obesity, insulin resistance, type-2 diabetes mellitus, hypertension, dyslipidemia, metabolic syndrome, nonalcoholic fatty liver disease and cardiovascular disease. PCOS affects 4$7 \%$ of reproductive-aged women. It is characterized by irregular menses and hyperandrogenism. The goal is to manage both the reproductive and metabolic components of PCOS [22-26].

The diagnosis of PCOS requires two of the following three criteria: (1) Oligo- or anovulation (2) Biochemical and/or clinical signs of hyperandrogenism (3) Polycystic ovaries documented by specified ultrasound criteria .The precise etiology of PCOS is still unknown. However, hypothalamic-pituitary axis abnormalities result in abnormal secretion of gonadotropin releasing hormone $(\mathrm{GnRH})$, resulting in an increase in luteinizing hormone $(\mathrm{LH})$, and a decrease in follicle stimulating hormone (FSH), and favoring ovarian over-production of testosterone is hypothesized. Other proposed pathophysiologies include an enzymatic defect of ovarian (or and adrenal) steroidogenesis which favors excess androgen production; and insulin resistance which drives the metabolic and reproductive abnormalities in PCOS [27-31].

It has been demonstrated that hyperinsulinemia (due to insulin resistance) stimulates ovarian theca cells from PCOS women to produce androgens. In addition to insulin resistance, women with PCOS appear to have impaired beta-cell function .Impaired glucose tolerance develops when the beta cell can no longer compensate for the insulin resistance. There is an increased risk of gestational diabetes in women with PCOS [32-34].
Lifestyle interventions are the cornerstone of PCOS therapy. Metformin inhibits the production of hepatic glucose and increases insulin sensitivity. In clinical trials, it has been shown to decrease risk of conversion from IGT to type- 2 diabetes. This finding has made metformin a potentially attractive therapy for diabetes prevention in other populations, including those with PCOS. Though metformin can induce ovulation in some women with PCOS, its continued use during pregnancy is controversial and is currently category B and further studies are needed to document its safety during pregnancy.

In PCOS, metformin may decrease androgen levels. Metformin appears to be an effective mode of enhancing ovulation, particularly in combination with clomiphenecitrate, in women with PCOS. Hence, fertility may improve with use of metformin. Beside metformin therapy, other treatment for PCOS include thiazolodinediones, hormonal contraceptive therapy (estrogen-progestin therapy), and anti-androgen therapy (spironolactone, flutamide, finasteride) [35-41].

\section{Recommendations}

At tertiary care diabetes centers, all patients should be screened for obesity, dyslipidemia, nephropathy, retinopathy and other diabetic metabolic risk factors to prevent further complications. Clinical guidelines should be used for the management of diabetic patients [42-53].

\section{References}

1. Moller DE (2000) Potential role of TNF-alpha in the pathogenesis of insulin resistance and type 2 diabetes. Trends Endocrinol Metab 11(6): 212-217.

2. Steppan CM, Bailey ST, Bhat S, Brown EJ, Banerjee RR, et al. (2001) The hormone resist in links obesity to diabetes. Nature 409(6818): 307-312.

3. Uysal KT, Wiesbrock SM, Marino MW, Hotamisligil GS (1997) Protection from obesity-induced insulin resistance in mice lacking TNF-alpha function. Nature 389(6651): 610-614.

4. Yamauchi T, Kamon J, Waki H, Terauchi Y, Kubota N, et al. (2001) The fat-derived hormone adiponectin reverses insulin resistance associated with both lipoatrophy and obesity. Nat Med 7(8): 941-946.

5. Yang Q Graham TE, Mody N, Preitner F, Peroni OD, et al. (2005) Serum retinol binding protein 4 contributes to insulin resistance in obesity and type 2 diabetes. Nature 436(7049): 356-362. 


\section{Diabetes and Obesity International Journal}

6. Shimomura I, Hammer RE, Richardson JA, Ikemoto S, Bashmakov Y, et al. (1998) Insulin resistance and diabetes mellitus in transgenic mice expressing nuclear SREBP-1c in adipose tissue: model for congenital generalized lipodystrophy. Genes Dev 12(20): 3182-3194.

7. Gavrilova 0, Marcus-Samuels B, Graham D, Kim JK, Shulman GI, et al. (2000) Surgical implantation of adipose tissue reverses diabetes in lipoatrophic mice. J Clin Invest 105(3): 271-278.

8. Shimomura I, Hammer RE, Ikemoto S, Brown MS, Goldstein JL (1999) Leptin reverses insulin resistance and diabetes mellitus in mice with congenital lipodystrophy. Nature 401: 73-76.

9. Oral EA, Simha V, Ruiz E, Andewelt A, Premkumar A, et al. (2002) Leptin-replacement therapy for lipodystrophy. N Engl J Med 346(8): 570-578.

10. Kovacs P, Stumvoll M (2005) Fatty acids and insulin resistance in muscle and liver. Best Pract Res Clin Endocrinol Metab 19(4): 625-635.

11. Dobbins RL, Chester MW, Daniels MB, Mc Garry JD, Stein DT (1998) Circulating fatty acids are essential for efficient glucose-stimulated insulin secretion after prolonged fasting in humans. Diabetes 47(10): 16131618.

12. McGarry JD, Dobbins RL (1999) Fatty acids, lipotoxicity and insulin secretion. Diabetologia 42(2): 128-138.

13. Sako Y, Grill VE (1990) A 48-hour lipid infusion in the rat time-dependently inhibits glucose-induced insulin secretion and B cell oxidation through a process likely coupled to fatty acid oxidation. Endocrinology 127(4): 1580-1589.

14. Poynten AM, Gan SK, Kriketos AD, Campbell LV, Chisholm DJ (2005) Circulating fatty acids, non-high density lipoprotein cholesterol and insulin-infused fat oxidation acutely influence whole body insulin sensitivity in non-diabetic men. J Clin Endocrinol Metab 90(2): 1035-1040.

15. Axelsen M, Smith U, Eriksson JW, Taskinen MR, Jansson PA (1999) Postprandial hypertriglyceridemia and insulin resistance in normoglycemic first-degree relatives of patients with type 2 diabetes. Ann Intern Med 131(1): 27-31.

16. Jensen MD, Haymond MW, Rizza RA, Cryer PE, Miles JM (1989) Influence of body fat distribution on free fatty acid metabolism inobesity. J Clin Invest 83(4): 1168-1173.

17. Pirro $M$, Mauriège $P$, Tchernof $A$, Cantin $B$, Dagenais GR, et al. (2002) Plasma free fatty acid levels and the risk of ischemic heart disease in men: prospective results from the Quebec Cardiovascular Study. Atherosclerosis 160(2): 377-384.

18. Miles JM, Wooldridge D, Grellner WJ, Windsor S, Isley WL, et al. (2003) Nocturnal and postprandial free fatty acid kinetics in normal and type 2 diabetic subjects: effects of insulin sensitization therapy. Diabetes 52(3): 675-681.

19. Bouchard C (1995) Genetics and the metabolic syndrome. Int J Obes Relat Metab Disord 12(S1): S52S59.

20. Klein S, Wadden T, Sugerman HJ (2002) AGA technical review on obesity. Gastroenterology 123(3): 882-932.

21. Calle EE, Thun MJ, Petrelli MJ, Rodriguez C, Heath CW (1999) Body-mass index and mortality in a prospective cohort of US adults. $\mathrm{N}$ Engl $\mathrm{J}$ Med 341(15): 1097-1105.

22. Dunaif A, Segal KR, Futterweit W, Dobrjansky A (1989) Profound peripheral insulin resistance, independent of obesity, in polycystic ovary syndrome. Diabetes 38(9): 1165-1174.

23. Ehrmann DA, Barnes RB, Rosenfield RL, Cavaghan MK, Imperial J (1999) Prevalence of impaired glucose tolerance and diabetes in women with polycystic ovary syndrome. Diabetes Care 22(1): 141-146.

24. Wild RA, Painter PC, Coulson PB, Carruth KB, Ranney GB (1985) Lipoprotein lipid concentrations and cardiovascular risk in women with polycystic ovary syndrome. J Clin Endocrinol Metab 61(5): 946-951.

25. Setji TL, Holland ND, Sanders LL, Pereira KC, Diehl AM, et al. (2006) Nonalcoholic steatohepatitis and nonalcoholic fatty liver disease in young women with polycystic ovary syndrome. J Clin Endocrinol Metab 91(5): 1741-1747.

26. Apridonidze T, Essah PA, Iuorno MJ, Nestler JE (2005) Prevalence and characteristics of the metabolic syndrome in women with polycystic ovary syndrome. J Clin Endocrinol Metab 90(4): 1929-1935.

27. Zawadzki JK, Dunaif A (1992) Diagnostic criteria for PCOS: towards a rational approach. In: Dunaif A, 


\section{Diabetes and Obesity International Journal}

Givens JR, Hazeltine FP, Merriam GR (Eds.), PCOS: current issues in endocrinology and metabolism, vol 4. Blackwell Scientific, Boston, pp: 235.

28. Rotterdam ESHRE/ASRM-Sponsored PCOS Consensus Workshop Group (20004) Revised 2003 consensus on diagnostic criteria and long-term health risks related to polycystic ovary syndrome. Fertil Steril 81(1): 19-25.

29. Balen AH, Laven JS, Tan SL, Dewailly D (2003) Ultrasound assessment of the polycystic ovary: international consensus definitions. Hum Reprod 9(6): 505-514.

30. American Association of Clinical Endocrinologists Polycystic ovary syndrome writing committee (2005) American Association of Clinical Endocrinologists position statement on metabolic and cardiovascular consequences of polycystic ovary syndrome. Endocr Pract 11(2): 126-134.

31. Dunaif A (1997) Insulin resistance and the polycystic ovary syndrome: mechanism and implications for pathogenesis. Endocr Rev 18(6): 774-800.

32. Ibanez L, Potau N, Francois I, de Zegher F (1998) Precocious pubarche, hyperinsulinism, and ovarian hyperandrogenism in girls: relation to reduced fetal growth. J Clin Endocrinol Metab 83(10): 3558-3662.

33. O'meara NM, Blackman JD, Ehrmann DA, Barnes RB, Jaspan JB, et al. (1993) Defects in beta-cell function in functional ovarian hyperandrogenism. J Clin Endocrinol Metab 76(5): 1241-1247.

34. Dunaif A, Finegood DT (1996) Beta-cell dysfunction independent of obesity and glucose intolerance in the polycystic ovary syndrome. J Clin Endocrinol Metab 81(3): 942-947.

35. American Diabetes Association (2005) Standards of medical care in diabetes. Diabetes Care 28(S1): S4S36.

36. Bates GW, Whitworth MS (1982) Effect of body weight reduction on plasma androgens in obese, infertile women. Fertil Steril 38(4): 406-409.

37. Huber-Bucholz MM, Carey DG, Norman RJ (1999) Restoration of reproductive potential by lifestyle modification in obese polycystic ovary syndrome: role of insulin sensitivity and luteinizing hormone. J Clin Endocrinol Metab 84(4): 1470-1474.
38. Velazquez EM, Mendoza S, Hamer T, Sosa F, Glueck CJ (1994) Metformin therapy in polycystic ovary syndrome reduces hyperinsulinemia, insulin resistance, hyperandrogenemia, and systolic blood pressure, whereas facilitating normal menses and pregnancy. Metabolism 43(5): 647-654.

39. Lord JM, Flight IH, Norman RJ (2003) Insulinsensitizing drugs (metformin, troglitazone, rosiglitazone, pioglitazone, D-chiro-inositol) forpolycystic ovary syndrome. Cochrane Database Syst Rev 3: CD003053.

40. Pasquali R, Gambineri A, Anconetani B, Vicennati V, Colitta D, et al. (1999) The natural history of the metabolic syndrome in young women with the polycystic ovary syndrome and the effect of long-term oestrogen-progestagen treatment. Clin Endocrinol 50(4): 517-527.

41. Ibanez L, Valls C, Ferrer A, Ong K, Dunger DB, et al. (2002) Additive effects of insulin-sensitizing and antiandrogen treatment in young, nonobese women with hyperinsulinism, hyperandrogenism, dyslipidemia, and an ovulation. J Clin Endocrinol Metab 87(6): 2870-2874.

42. Aziz MA (2016) Association of Hypothyroidism, Body Mass Index, Systolic Blood Pressure and Proteinuria in Diabetic Patients: Does treated Hypothyroid with Thyroxine Replacement Therapy prevent Nephropathy/ Chronic Renal Disease? Current Diabetes Reviews 12(3): 297-306.

43. Aziz MA (2016) Association of Hypothyroidism with High Non-HDL Cholesterol and Ankle Brachial Pressure Index in Patients with Diabetes: 10-Year Results from a 5780 Patient Cohort. A Need for Intervention. Annals Thyroid Res 2(2): 53-57.

44. Aziz KMA (2017) Association of Serum Lipids with High Blood Pressure and Hypertension among Diabetic Patients. Mathematical Regression Models to Predict Blood Pressure from Lipids. An Experience from 12-year Follow Up of more than 9000 Patients' Cohort. Gen Med (Los Angeles) 5(5): 297.

45. Aziz KMA (2013) Association between Non-HDL and HDL Cholesterol with microalbuminuria in patients with Diabetes. Journal of Diabetology 4(1): 1-6.

46. Aziz KMA (2015) Correlation of Urine Biomarkers: Microalbuminuria and Spot Urine Protein among Diabetic Patients. Application of Spot Urine Protein in Diabetic Kidney Disease, Nephropathy, Proteinuria 


\section{Diabetes and Obesity International Journal}

Estimation, Diagnosing and Monitoring. Recent Pat Endocr Metab Immune Drug Discov 9(2): 121-133.

47. Aziz KMA (2014) Association of Microalbuminuria with Ischemic Heart Disease, Dyslipidemia and Obesity among Diabetic Patients: Experience from 5 Year Follow up Study of 1415 Patients. Bioenergetics 3: 118 .

48. Aziz KMA (2012) Targeting LDL Dyslipidemia for Controlling Progression of Nephropathy in Diabetic Population: A Cross Sectional Analytical Study. Journal of the Dow University of Health Sciences 6(1): 7-11.

49. Aziz KMA (2012) Management of Type- 1 and Type- 2 Diabetes by Insulin Injections in Diabetology Clinics A Scientific Research Review. Recent Pat Endocr Metab Immune Drug Discov 6(2): 148-170.

50. Aziz KMA (2014) Unique glycemic and cardio-renal protective effects of metformin therapy among type- 2 diabetic patients: a lesson from a five-year crosssectional observational study of 1590 patients. Research 1: 874.

51. Aziz KMA (2017) Application of Premixed Insulin NovoMix ${ }^{\circledR} 30$ and NovoRapid ${ }^{\circledR}$ as Multiple Daily Injections or as Basal Bolus Format in Selected Diabetic Patients: Technical Evidence from Prospective Case Series. Int J Diabetol Vasc Dis Res 5(2e): $1-2$.

52. Aziz KMA (2017) The Art and Science of Managing Diabetic Pregnancy by Insulin Injections and Insulin Pump: Evidence Based Reports from Research Trials and Meta-Analysis. Gen Med (Los Angeles) 5: e113.

53. Aziz KMA (2017) Using Premixed Biphasic Insulin Analogs Humalog® Mix 25 and Humalog@ Mix 50 in Basal Bolus Format: Evidence from Research, Clinical Practice and Case Reports. J Diabetes Metab Disord Control 4(3): 00114. 